\title{
Opeatogenys gracilis (Pisces: Gobiesocidae): an overlooked species or another 'Mediterranean endemism' found in Atlantic waters?
}

\author{
E. J. Gonçalves*†, R. Beldade* and M. Henriques*† \\ *Eco-Ethology Research Unit, Instituto Superior de Psicologia Aplicada, R. Jardim \\ do Tabaco 34, 1149-041 Lisboa, Portugal and \$Parque Natural da Arrábida, Praça \\ da República, 2900 Setúbal, Portugal
}

(Received 20 April 2004, Accepted 21 February 2005)

\begin{abstract}
The occurrence of Opeatogenys gracilis outside the Mediterranean Sea is confirmed for the first time. This is probably a more common species than previously thought, but its apparent complete dependence on seagrass beds suggests the possibility of including it in the IUCN threatened species list. Some sex differences are described and a complete meristic and morphometric description of the species is presented. The occurrence of the species in the north-east Atlantic indicates that it might be a recent dispersal from the Mediterranean Sea, or an overlooked part of the autochthonous fauna.

(C) 2005 The Fisheries Society of the British Isles
\end{abstract}

Key words: north-east Atlantic; Opeatogenys gracilis; seagrass beds.

\section{INTRODUCTION}

Opeatogenys gracilis (Canestrini) is a poorly studied gobiesocid that lives in seagrass beds (Hofrichter, 1995). It is a very small fish with a total length $\left(L_{\mathrm{T}}\right)$ of only $c .3 \cdot 0 \mathrm{~cm}$ (Briggs, 1986). This species was first described by Canestrini (1864) as Mirbelia gracilis, based on one specimen collected in Nice (southern France). Moreau (1881) did not agree with Canestrini's description of the new genus and placed this species in the genus Lepadogaster, as L. gracilis (Griffini, 1903). Briggs (1955) examined a specimen noted by Carus (1893) and described the genus Opeatogenys, at the time a monospecific genus. Later, Briggs (1957) described a second species, Opeatogenys cadenati Briggs, also occurring in seagrass beds in western Africa (Ghana and Senegal; Briggs, 1957). Opeatogenys cadenati is now also known from Morocco (Brownell, 1978) and the Canary Islands (Brito, 1991). Briggs (1986) does not provide any common name for $O$. gracilis, probably because its very small size and cryptic habits means that it is infrequently encountered by non-scientists who might give it a vernacular name. Bini (1968), however, cites the name 'pygmy clingfish', and Debelius (1997) uses the name 'seagrass clingfish'.

$†$ Author to whom correspondence should be addressed. Tel.: +351.218811700; fax: +351.218860954 ; email: emanuel@ispa.pt 
No type specimens of $O$. gracilis are known (Eschmeyer, 2004) and, until recently, only a few specimens had been collected in the Mediterranean Sea. Briggs (1986) described the distribution of this species as extending from Nice to the Adriatic. One specimen was described by Carus (1893) from Messina (Sicily); another specimen was reported by Kolombatovic (1900) associated with Posidonia oceanica (L.) Delile in the Adriatic. Dieuzeide et al. (1955) refer to the occurrence of some specimens of $O$. gracilis in $P$. oceanica meadows in Algeria. More recently, Reina-Hervás \& Nuñez Vergara (1985) described two specimens found in Cymodocea nodosa (Ucria) Ascherton beds in Málaga (Spain). Cardona \& Guerao (1992) collected five specimens from C. nodosa and Caulerpa prolifera (Forsskaal) Lamouroux meadows in Cataluña (Spain). Hofrichter (1995) confirmed the presence of the species at previous sites (Adriatic and Sicily) and also described its occurrence in Cyprus, France (Banyuls-sur-Mer) and Ibiza (capturing, for the first time, a large number of specimens). Hofrichter \& Patzner (2000), studying clingfishes associated with $P$. oceanica and $C$. nodosa, cited a maximum abundance of eight individuals $\mathrm{m}^{-2}$, and noted the occurrence of $O$. gracilis at depths of up to $20 \mathrm{~m}$. Finally, Vizzini \& Scilipoti (1999) and Vizzini et al. (2001) captured 275 specimens from $P$. oceanica meadows in western and northern Sicily, and suggested that this must be a more common species than previously thought. Gonçalves (1941), reviewing an old collection by King D. Carlos I of Portugal, found a specimen classified as Mirbelia gracilis collected in the Sado River (western Portugal) in 1897. This author has not confirmed the identity of the specimen and refers to it as Lepadogaster sp.

In this paper the occurrence of $O$. gracilis outside the Mediterranean Sea was investigated, some old records were revised, and a complete meristic and morphometric description of the species was undertaken to determine the main differences between the sexes. Hypotheses explaining the Atlantic occurrence of this species, otherwise known only from the Mediterranean Sea are also discussed.

\section{MATERIALS AND METHODS}

Specimens were collected at two locations on the Portuguese coast, the Ria Formosa ( $n=26$, collected on 23 February 2001), southern Portugal ( $\left.36^{\circ} 59^{\prime} \mathrm{N} ; 7^{\circ} 51^{\prime} \mathrm{W}\right)$ and the Sado estuary $(n=4$, three collected on 6 June 2001 and one on 10 July 2003), western coast $\left(38^{\circ} 27^{\prime} \mathrm{N} ; 8^{\circ} 43^{\prime} \mathrm{W}\right)$. Ria Formosa is a coastal lagoon in permanent connection with the sea, formed by a succession of sand barrier islands along the south coast of Portugal. Inside the lagoon extensive seagrass beds ( $C$. nodosa and Zostera marina L.) occur at shallow depths (<6-7 m) (Alberto et al., 2001; Billingham et al., 2003). The Sado estuary has high salinity levels throughout the year (Cabral, 2000). Some sparse beds of Z. marina and Zostera noltii Hornemann are present at depths of $<5-6 \mathrm{~m}$. At both sites, fish were collected using SCUBA by dragging a fine mesh $(<1 \mathrm{~mm})$ hand net along seagrass leaves. Specimens were killed with an overdose of the anaesthetic MS222, fixed in formalin (10\% diluted in sea water) and preserved in $70 \%$ alcohol. Biometric measurements were carried out using callipers $\left(L_{\mathrm{T}}\right.$ and standard length, $\left.L_{\mathrm{S}}\right)$ and a dissecting microscope with an ocular micrometer to the nearest $0.01 \mathrm{~mm}$. The following measurements were taken, after Briggs (1955): $L_{\mathrm{T}}, L_{\mathrm{S}}$, head length (HL), head width (HW), head height $\left(L_{\mathrm{H}}\right)$, snout length $(\mathrm{SnL})$, eye diameter (Eye), interorbital distance (IOD), dorsal fin length (DFL), anal fin length (AFL), caudal peduncle length (CPL), caudal peduncle height $(\mathrm{CPH})$, caudal fin length (CFL), pelvic disc length (DiL), pelvic disc width (DiW), 
distance from the anus to the anal fin base (AnAFB), distance from the anus to the pelvic disc (AnDi), pre-pelvic disc distance (PreDi), pre-dorsal fin length (PreDFL), pre-anal fin length (PreAFL), length of the urogenital papilla $\left(L_{\mathrm{UP}}\right)$, width of the urogenital papilla (UPW), depth at anus (dA), dorsal-caudal distance (DC), postdorsal distance (PDD) and postdorsal-caudal distance (PDC). Specimens were sexed by external examination of the urogenital papilla. The number of rows of flattened dermal papillae in the pelvic disc regions A, B and C, follow Briggs $(1955,1986)$ descriptions. All specimens were catalogued in the collection of the Arrábida Nature Park Oceanographic Museum (Portinho da Arrábida, Portugal).

The specimen from the King D. Carlos I collection deposited at the Vasco da Gama Aquarium in Lisbon (catalogue number 293) was carefully analysed to confirm its taxonomic status. An additional Mediterranean specimen from the Natural History Museum (London) (catalogue number BMNH 1995.3.15.1), captured at Banyulssur-Mer, France, was examined for comparative purposes. The only other specimen found is no longer suitable for meristic and morphometric measurements. This is the specimen noted by Carus (1893) and examined by Briggs (1955), which belongs to the California Academy of Sciences collection (catalogue number 147898), and has been cleared and stained.

Size differences $\left(L_{\mathrm{S}}\right)$ between sexes were tested using a $t$-test for independent samples. All other variables, which could be influenced by allometry, were divided by $L_{\mathrm{S}}$, arcsine $(\sqrt{p})$ transformed (Sokal \& Rohlf, 1981) (where $\mathrm{p}$ is the value of the proportion) and tested for sex-differences using the $t$-test for independent samples. In one case $\left(L_{\mathrm{UP}} L_{\mathrm{S}}{ }^{-1}\right)$, the homogeneity of variances assumption could not be met (Levene's test) and a MannWhitney $U$ test was used. To test for sex differences in the body proportions (as in Briggs, 1955), variables were $\log _{10}$ transformed (Sokal \& Rohlf, 1981) and tested using the $t$-test for independent samples. Results were considered significantly different if $P<0.05$ (twotailed). All tests were performed using the STATISTICA computer package.

\section{RESULTS}

Morphometric characteristics of the specimens collected in this study are presented in Table I. No difference in size $\left(L_{S}\right)$ between sexes was found $(P=0 \cdot 46)$. Males and females, however, differ significantly in the following measurements (as proportion of $L_{\mathrm{S}}$ ) (Table II): anal fin length (AFL; $P<0.05)$, urogenital papilla length $\left(L_{\mathrm{UP}}\right.$; Mann-Whitney $U$ test, $\left.P<0.001\right)$ and width (UPW; $P<0.001$ ), and dorsal-caudal distance (DC; $P<0 \cdot 05$ ). In the body proportions analysed (as in Briggs, 1955), only the eye diameter in interorbital space was also significantly different between sexes $(P<0.05)$ (Table III).

For meristic characters the values are (number of individuals in parentheses): dorsal fin rays $3(21)$ or 4(9); anal fin rays $3(11)$ or 4(19); pectoral fin rays $15(10)$ or 16(20); caudal fin rays $8(16), 9(6)$ or $10(8)$; rows of flattened papillae in pelvic disc region A 4(26) or 5(4), pelvic disc region B 4(20) or 5(10) and pelvic disc region $C 3(20), 4(8)$ or $5(2)$.

Briggs (1957) stated that $O$. cadenati can be distinguished from $O$. gracilis based on the following characteristics. Opeatogenys cadenati: body depth $6 \cdot 0(5 \cdot 7$ $-6 \cdot 2)$ in $L_{\mathrm{s}}$; pectoral fin rays $21(20-22)$; upper attachment of gill membrane opposite 4th (4-5) pectoral ray; upper attachment of axial, dermal flap opposite 10th (9-11) pectoral ray; seven short, blunt rakers present on the third gill arch. Opeatogenys gracilis: body depth $7 \cdot 1$ in $L_{\mathrm{s}}$; pectoral fin rays 16 ; upper attachment of gill membrane opposite 3rd pectoral ray; upper attachment of axial, 


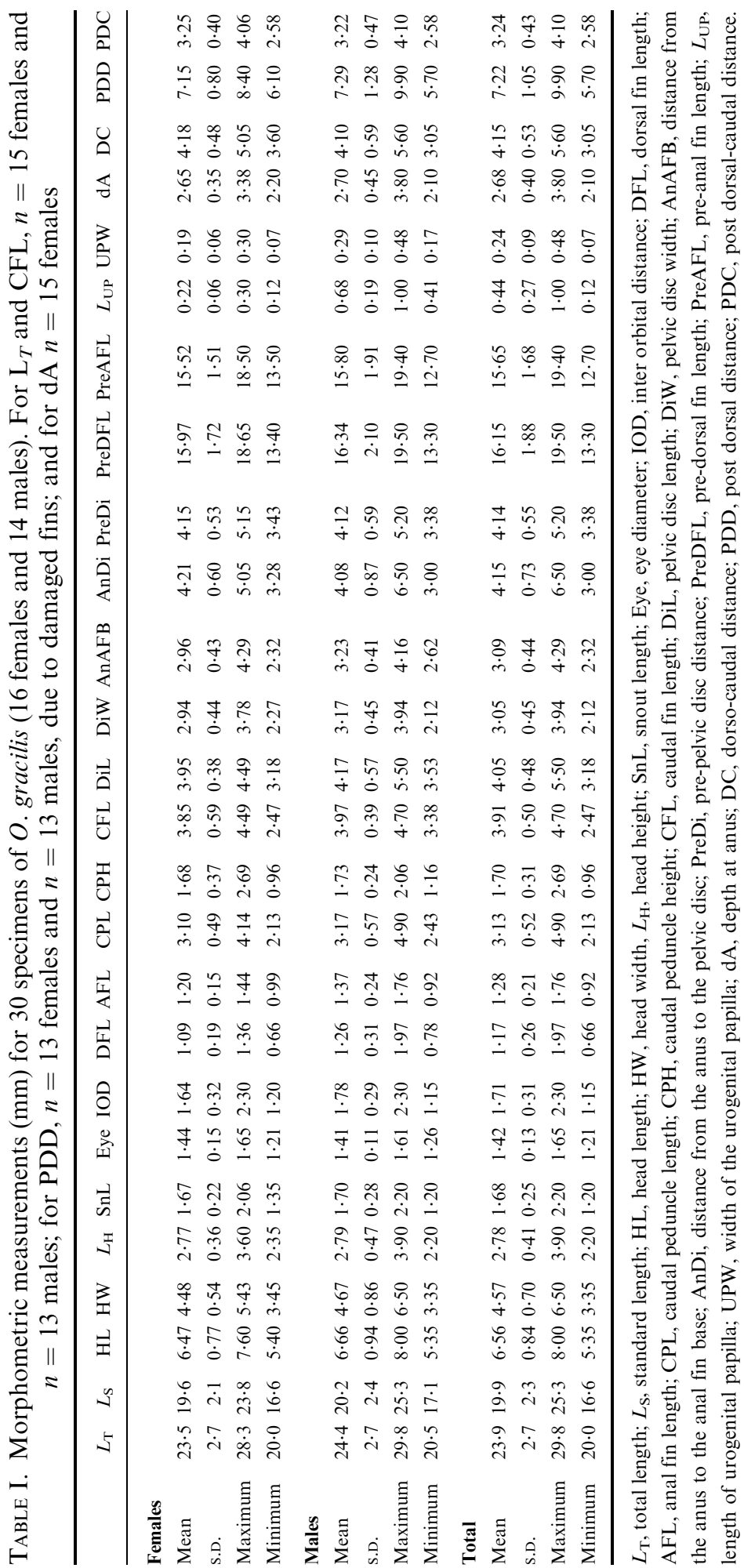


TABLE II. Proportions (as percentage of $L_{\mathrm{S}}$ in $\mathrm{mm}$ ) for 30 specimens of O. gracilis (16 females and 14 males) which revealed significant differences between sexes (see Table I for abbreviations)

\begin{tabular}{lcccr}
\hline & AFL & $L_{\mathrm{UP}}$ & UPW & DC \\
\hline Females & & & & \\
Mean & $6 \cdot 12$ & $1 \cdot 14$ & $0 \cdot 98$ & $21 \cdot 34$ \\
S.D. & $0 \cdot 74$ & $0 \cdot 26$ & $0 \cdot 28$ & $1 \cdot 24$ \\
Maximum & $8 \cdot 23$ & $1 \cdot 52$ & $1 \cdot 52$ & $23 \cdot 08$ \\
Minimum & $5 \cdot 29$ & $0 \cdot 66$ & $0 \cdot 38$ & $18 \cdot 93$ \\
Males & & & & \\
Mean & $6 \cdot 77$ & $3 \cdot 33$ & $1 \cdot 43$ & $20 \cdot 28$ \\
S.D. & $0 \cdot 93$ & $0 \cdot 70$ & 0.33 & $1 \cdot 59$ \\
Maximum & $8 \cdot 39$ & $4 \cdot 42$ & $2 \cdot 11$ & $22 \cdot 33$ \\
Minimum & $5 \cdot 24$ & $2 \cdot 36$ & 0.97 & $17 \cdot 04$ \\
\hline
\end{tabular}

dermal flap opposite 7 th pectoral ray; five short, blunt rakers present on the third gill arch.

Hofrichter (1995), however, examined the differences between these two species and reported that the only character that presents no overlap between the

TABLE III. Body proportions as in Briggs (1955) for the 30 specimens of O. gracilis (16 females and 14 males), and for the BMNH specimen. $L_{\mathrm{H}}$ in $L_{\mathrm{S}}$ is not presented for this specimen since the head is slightly damaged (see Table I for abbreviations)

\begin{tabular}{|c|c|c|c|c|c|c|c|c|}
\hline & $\begin{array}{c}L_{\mathrm{H}} \\
\text { in } L_{\mathrm{S}}\end{array}$ & $\begin{array}{c}\mathrm{CPH} \\
\text { in } \mathrm{CPL}\end{array}$ & $\begin{array}{l}\mathrm{HL} \\
\text { in } L_{\mathrm{S}}\end{array}$ & $\begin{array}{l}\mathrm{HW} \\
\text { in } L_{\mathrm{S}}\end{array}$ & $\begin{array}{l}\text { SnL } \\
\text { in HL }\end{array}$ & $\begin{array}{c}\text { Eye } \\
\text { in IOD }\end{array}$ & $\begin{array}{c}\text { Eye } \\
\text { in HL }\end{array}$ & $\begin{array}{l}\text { DiL } \\
\text { in } L_{\mathrm{S}}\end{array}$ \\
\hline \multicolumn{9}{|l|}{ Females } \\
\hline Mean & $7 \cdot 11$ & 1.91 & $3 \cdot 04$ & $4 \cdot 40$ & $3 \cdot 90$ & $1 \cdot 14$ & $4 \cdot 50$ & $4 \cdot 97$ \\
\hline S.D. & $0 \cdot 55$ & $0 \cdot 43$ & $0 \cdot 14$ & $0 \cdot 32$ & $0 \cdot 26$ & $0 \cdot 19$ & $0 \cdot 28$ & $0 \cdot 32$ \\
\hline Maximum & $8 \cdot 13$ & $3 \cdot 03$ & $3 \cdot 25$ & $5 \cdot 00$ & $4 \cdot 37$ & $1 \cdot 43$ & $4 \cdot 96$ & $5 \cdot 74$ \\
\hline Minimum & $6 \cdot 01$ & $1 \cdot 18$ & $2 \cdot 77$ & $3 \cdot 99$ & $3 \cdot 57$ & $0 \cdot 79$ & $3 \cdot 81$ & $4 \cdot 39$ \\
\hline \multicolumn{9}{|l|}{ Males } \\
\hline Mean & $7 \cdot 31$ & $1 \cdot 85$ & $3 \cdot 05$ & $4 \cdot 39$ & $3 \cdot 96$ & $1 \cdot 26$ & $4 \cdot 73$ & $4 \cdot 87$ \\
\hline S.D. & $0 \cdot 52$ & $0 \cdot 30$ & $0 \cdot 19$ & $0 \cdot 41$ & $0 \cdot 38$ & $0 \cdot 14$ & $0 \cdot 45$ & $0 \cdot 25$ \\
\hline Maximum & $8 \cdot 24$ & $2 \cdot 53$ & $3 \cdot 32$ & $5 \cdot 25$ & $4 \cdot 83$ & $1 \cdot 53$ & $5 \cdot 38$ & $5 \cdot 32$ \\
\hline Minimum & $6 \cdot 49$ & $1 \cdot 51$ & $2 \cdot 78$ & $3 \cdot 89$ & $3 \cdot 55$ & $0 \cdot 91$ & $3 \cdot 93$ & $4 \cdot 52$ \\
\hline \multicolumn{9}{|l|}{ Total } \\
\hline Mean & $7 \cdot 20$ & $1 \cdot 88$ & $3 \cdot 05$ & $4 \cdot 39$ & $3 \cdot 94$ & $1 \cdot 21$ & $4 \cdot 62$ & $4 \cdot 91$ \\
\hline S.D. & $0 \cdot 55$ & $0 \cdot 38$ & $0 \cdot 16$ & $0 \cdot 36$ & $0 \cdot 32$ & $0 \cdot 17$ & $0 \cdot 38$ & $0 \cdot 29$ \\
\hline Maximum & $8 \cdot 24$ & $3 \cdot 03$ & $3 \cdot 32$ & $5 \cdot 25$ & $4 \cdot 83$ & $1 \cdot 53$ & $5 \cdot 38$ & $5 \cdot 74$ \\
\hline Minimum & $6 \cdot 01$ & $1 \cdot 18$ & $2 \cdot 77$ & $3 \cdot 89$ & $3 \cdot 55$ & $0 \cdot 79$ & $3 \cdot 81$ & $4 \cdot 39$ \\
\hline \multicolumn{9}{|l|}{ BMNH specimen } \\
\hline & & $2 \cdot 66$ & $2 \cdot 89$ & $4 \cdot 37$ & $3 \cdot 28$ & $1 \cdot 00$ & $4 \cdot 21$ & $4 \cdot 27$ \\
\hline
\end{tabular}

BMNH, British Museum of Natural History. 
species is the number of pectoral fin rays. In order to establish that the specimens belonged to $O$. gracilis and not $O$. cadenati or some undescribed species a search was also made for available material from museum collections. Although only one specimen was available (BMNH 1995.3.15.1; see Material and Methods), data from this specimen and from the literature show that there are no morphological differences between the present specimens and Mediterranean Sea ones (Table III). Also, the numbers of pectoral fin rays in the present specimens (15 or 16) are clearly different from the numbers reported for O. cadenati by Briggs (1957) (20 to 22 pectoral fin rays).

Thus, the description by Briggs (1955) of $O$. gracilis, based on a single specimen, can now be updated based on material examined in this study (Table III): body depth $7 \cdot 2(6 \cdot 0-8 \cdot 2)$ in $L_{S}$; caudal peduncle height $1 \cdot 9(1 \cdot 2-3 \cdot 0)$ in its length; head length $3 \cdot 1(2 \cdot 8-3 \cdot 3)$ in $L_{S}$; head width $4 \cdot 4(3 \cdot 9-5 \cdot 3)$ in $L_{S}$; snout length $3 \cdot 9$ $(3 \cdot 6-4 \cdot 8)$ in head length; eye diameter $1 \cdot 2(0 \cdot 8-1 \cdot 5)$ in bony interorbital space and $4 \cdot 6(3 \cdot 8-5 \cdot 4)$ in head length; length of disc $4 \cdot 9(4 \cdot 4-5 \cdot 7)$ in $L_{\mathrm{S}}$. Taking into consideration all specimens described in the literature (Briggs, 1955; ReinaHervás \& Nuñez Vergara, 1985; Cardona \& Guerao, 1992; Hofrichter, 1995; Vizzini \& Scilipoti, 1999; Vizzini et al., 2001), the meristic counts for the species are: dorsal fin rays 2-4; anal fin rays 2-4; pelvic fin rays 4; pectoral fin rays 14 -18 ; caudal fin rays 8-14; rows of flattened papillae in disc region A $4-5$, disc region $\mathrm{B} 4-5$ and disc region $\mathrm{C} 3-5$. The maximum known size is $27 \cdot 0 \mathrm{~mm} L_{\mathrm{S}}$ $\left(33 \cdot 0 \mathrm{~mm} L_{\mathrm{T}}\right)$ (Cardona \& Guerao, 1992).

Body colouration of the specimens analysed varies from light green to light brown and dark red sometimes with small blue iridescent spots along the flanks (Reina-Hervás \& Nuñez Vergara, 1985; Hofrichter \& Patzner, 2000).

The specimen of the King D. Carlos I collection, in spite of being in very bad condition, could clearly be identified as $O$. gracilis $\left(L_{\mathrm{T}}=25.0 \mathrm{~mm} ; L_{\mathrm{S}}=20.0 \mathrm{~mm}\right.$; fin rays: dorsal 3; anal 3; pectoral 15/16).

\section{DISCUSSION}

A marked sexual dimorphism was found in the size and shape of the urogenital papilla in $O$. gracilis [also described for O. cadenati by Briggs (1957)], which can clearly be used to separate both sexes. This dimorphism was predicted by Briggs (1955) who described a long, slender genital papilla in the specimen he examined (a male). Males and females also differ significantly in anal fin length, dorsal-caudal distance and eye diameter in interorbital space. These characters are thus useful for distinguishing the two sexes in this species, since they present quite similar colours and morphology.

The occurrence of $O$. gracilis outside the Mediterranean Sea is described here for the first time. The presence of this species on the Portuguese coast, however, can be traced back to the late 19th century (given the existence of the specimen collected during the King D. Carlos I oceanographic expeditions). The occurrence of Mediterranean Sea coastal fish species on nearby Atlantic shores has been documented in recent years (Nieto \& Alberto, 1992; Almada et al., 1993; Gonçalves et al., 1993; Henriques et al., 1999; Bañón et al., 2002). It is not clear, however, if these recent findings result from an increased research effort in the Portuguese and Spanish Atlantic coasts (Almada et al., 2001) or if the 
distributions of these species are changing as a result of global warming. In fact, water temperature has been increasing steadily on the Portuguese coast since the 1940s (Lemos \& Pires, 2004), but the nearshore ichthyofauna was largely unknown until recently. The case of $O$. gracilis is further complicated by the fact that this is a very cryptic species that occurs exclusively in seagrasses and that can only be sampled using small mesh size nets. Although there is no direct evidence to support the hypothesis that the Portuguese distribution is associated with global warming, the fact that a specimen of this species was collected in the late 19th century in Portugal could also support either argument; that this is an abundant but overlooked species of small size which occurs exclusively in seagrasses, or that the late 19th century was a period of increase in seawater temperature in the north-eastern Atlantic (Southward et al., 1995; Levitus et al., 2000), resulting in the presence of this species in this region at that time.

Although this might be an abundant species, its apparent strict dependence upon seagrass beds and the overall decline of these beds in the Atlantic due to anthropogenic action and seaweed infestations (den Hartog \& Polderman, 1975; Bortone, 2000) suggest that this is a possible candidate for the IUCN Red List of Threatened Species. The species might be listed in the data deficient (DD) category (IUCN, 2004) because more information is required for this species and there is the possibility that future research will show a threatened classification is appropriate. More detailed studies focused on seagrasses in the northeastern Atlantic and the Mediterranean Sea using adequate techniques for collecting this very small and cryptic species, however, are needed to clarify the distribution, range, and ecology of $O$. gracilis.

Part of this study was supported by the Portuguese Science and Technology Foundation (Fundação para a Ciência e a Tecnologia - FCT) through the Pluriannual Program (R\&D Unit 331/94) and as part of the project POCTI/BSE/38350/2001, and by a project from the Institute for Nature Conservation (ICN). RB was supported by a PhD grant by FCT (SFRH/BD/1013/2000). The authors would like to thank A. Kazem for reviewing the English and J. Martins for his assistance in the field work.

\section{References}

Alberto, F., Mata, L. \& Santos, R. (2001). Genetic homogeneity in the seagrass Cymodocea nodosa at its northern Atlantic limit revealed through RAPD. Marine Ecology Progress Series 221, 299-301.

Almada, V. C., Oliveira, R. F., Gonçalves, E. J., Almeida, A. J. \& Barata, E. N. (1993). A new northern limit for the distribution range of Lipophrys canevae (Pisces: Blenniidae) in the Atlantic Ocean. Arquivos do Museu Bocage - Nova Série 2, 403-408.

Almada, V. C., Henriques, M. \& Gonçalves, E. J. (2001). The study of inshore fishes in Portugal - a brief history and prospects for the future. Boletim do Museu Municipal do Funchal Supplement 6, 289-310.

Bañón, R., del Rio, J. L., Piñeiro, C. \& Casas, M. (2002). Occurrence of tropical affinity fish in Galician waters, north-west Spain. Journal of the Marine Biological Association of the United Kingdom 82, 877-880.

Billingham, M. R., Reusch, T. B. H., Alberto, F. \& Serrão, E. A. (2003). Is asexual reproduction more important at geographical limits? A genetic study of the seagrass Zostera marina in the Ria Formosa, Portugal. Marine Ecology Progress Series 265, 77-83. 
Bini, G. (1968). Atlante dei Pesci delle Coste Italiane, Vol. 6. Roma: Mondo Sommerso Editrice.

Bortone, S. A. (Ed.) (2000). Seagrasses: Monitoring, Ecology, Physiology, and Management. Boca Raton, FL: CRC Press.

Briggs, J. C. (1955). A monograph of the clingfishes (order Xenopterygii). Stanford Ichthyological Bulletin 6, 1-224.

Briggs, J. C. (1957). A new genus and two new species of eastern Atlantic clingfishes. Copeia 1957, 204-208.

Briggs, J. C. (1986). Gobiesocidae. In Fishes of the North-Eastern Atlantic and the Mediterranean (Whitehead, P. J. P., Bauchot, M.-L., Hureau, J.-C., Nielsen, J. \& Tortonese, E., eds), pp. 1351-1359. Paris: UNESCO.

Brito, A. (1991). Catalogo de los Peces de Las Islas Canarias. La Laguna: Francisco Lemos.

Brownell, C. L. (1978). Sur quelques collections de poissons littoraux de l'Atlantique Marocain. Bulletin de l'Institut des Pêches Maritimes 23, 111-133.

Cabral, H. (2000). Distribution and abundance patterns of flatfishes in the Sado estuary, Portugal. Estuaries 23, 351-358.

Canestrini, G. (1864). Studi sui Lepadogaster del Mediterraneo. Archivio per la Zoologia l'Anatomia e la Fisiologia 3, 177-196.

Cardona, L. \& Guerao, G. (1992). Primera cita de Opeatogenys gracilis (Canestrini, 1864) (Osteichthyes, Gobiesocidae) en el litoral Catalán. Miscellanea Zoologica 16, 243-245.

Carus, J. V. (1893). Prodromus faunae Mediterraneae sive descriptio animalium maris Mediterranei incolarum quam comparata silva rerum quatenus innotuit adiectis locis et nominibus vulgaribus... Stuttgart: E. Schweizerbart'sche Verlagshandlung.

Debelius, H. (1997). Mediterranean and Atlantic Fish Guide. Frankfurt: IKAN Unterwasserarchiv.

Dieuzeide, R., Novella, M. \& Roland, J. (1955). Catalogue des poissons des côtes Algériennes. Bulletin des Travaux de la Station D'aquiculture et de Pêche de Castiglione 6, 1-384.

Gonçalves, B. C. (1941). Colecção oceanográfica de D. Carlos I - Peixes. Travaux de la Station de Biologie Maritime de Lisbonne 46, 1-108.

Gonçalves, E. J., Almada, V. C., Almeida, A. J. \& Oliveira, R. F. (1993). On the occurrence of Parablennius sanguinolentus (Pisces: Blenniidae) on the Portuguese coast. Journal of the Marine Biological Association of the United Kingdom 73, 465-467.

Griffini, A. (1903). Ittiologica Italiana. Milano: Ulrico Hoepli.

den Hartog, C. \& Polderman, P. J. G. (1975). Changes in the seagrass populations of the Dutch Waddenzee. Aquatic Botany 1, 141-147.

Henriques, M., Gonçalves, E. J. \& Almada, V. C. (1999). The conservation of littoral fish communities: a case study at Arrábida coast (Portugal). In Behaviour and Conservation of Littoral Fishes (Almada, V. C., Oliveira, R. F. \& Gonçalves, E. J., eds), pp. 473-519. Lisboa: ISPA.

Hofrichter, R. (1995). Taxonomie, Verbreitung und Ökologie von Schildfischen der Unterfamilie Lepadogastrinae (Gobiesocidae, Teleostei). PhD Thesis, University of Salzburg, Austria.

Hofrichter, R. \& Patzner, R. A. (2000). Habitat and microhabitat of Mediterranean clingfishes (Teleostei: Gobiesociformes: Gobiesocidae). Marine Ecology (PSZN) 21, 41-53.

Kolombatovic, J. (1900). Druge zoologicke vijesti iz Dalmacije. Split.

Lemos, R. T. \& Pires, H. O. (2004). The upwelling regime off the west Portuguese coast, 1941-2000. International Journal of Climatology 24, 511. doi: 10.1002/ joc. 1009

Levitus, S., Antonov, J. I., Boyer, T. P. \& Stephens, C. (2000). Warming of the world ocean. Science 287, 2225-2229.

Moreau, E. (1881). Histoire Naturelle des Poissons de la France. Paris: Masson. 
Nieto, P. \& Alberto, L. J. (1992). The presence of Zebrus zebrus (Risso, 1826) (Gobiidae) on the Atlantic coast of Spain. Cybium 16, 137-144.

Reina-Hervás, J. A. \& Nuñez Vergara, J. C. (1985). Opeatogenys gracilis (Canestrini, 1864) (Gobiesocidae, Osteichthyes) en el Mediterráneo Español. Miscellanea Zoologica 9, 405-407.

Sokal, R. R. \& Rohlf, F. J. (1981). Biometry - The Principles and Practice of Statistics in Biological Research, 2nd edn. New York: W. H. Freeman \& Co.

Southward, A. J., Hawkins, S. J. \& Burrows, M. T. (1995). Seventy years' observation of changes in distribution and abundance of zooplankton and intertidal organisms in the western English Channel in relation to rising sea temperature. Journal of Thermal Biology 20, 127-155.

Vizzini, S. \& Scilipoti, D. (1999). Prima segnalazione di Opeatogenys gracilis (Canestrini, 1864) (Osteichthyes: Gobiesocidae) in un'area della Sicilia occidentale (Stagnone di Marsala). Biologia Marina Mediterranea 6, 627-629.

Vizzini, S., Mazzola, A. \& Scilipoti, D. (2001). Notes on the biology and ecology of Opeatogenys gracilis (Canestrini 1864) (Pisces: Gobiesocidae) from coastal environments in Sicily (Mediterranean). In Mediterranean Ecosystems: Structures and Processes (Faranda, F. M., Guglielmo, L. \& Spezie, G., eds), pp. 221-224. Milano: Springer Verlag Italia.

\section{Electronic References}

Eschmeyer, W. N. (Ed.). (2004). Catalog of Fishes. On-line edition. San Francisco, CA: California Academy of Sciences. Available from: http:/www.calacademy.org/ research/ichthyology/catalog/fishcatsearch.html. (Accessed December 9, 2004).

IUCN (2004). 2004 IUCN Red List of Threatened Species. Available from: www. iucnredlist.org. (Downloaded on December 10, 2004). 